\title{
A Causality Investigation of Taxation and Manufacturing Sector Growth in Nigeria (1990-2018)
}

\author{
Andabai, Priye Werigbelegha Ph.D* \\ Department of Banking and Finance, Niger Delta University, Bayelsa State, Nigeria
}

*Corresponding Author: Andabai, Priye Werigbelegha Ph.D, Department of Banking and Finance, Niger Delta University, Bayelsa State, Nigeria

\begin{abstract}
The study investigates the causality between taxation and manufacturing sector growth in Nigeria; for the period 1990-2018. Secondary data were used and collected from Central Bank of Nigeria Statistical Bulletin. The study employs Manufacturing sector output as proxy for Manufacturing sector growth and used as the dependent variable; whereas, inflation rate, value added tax and petroleum profit tax were used as explanatory variables to measure taxation. Hypotheses are formulated and tested using Ordinary Least Square econometrics technique. The findings revealed that the variables do not have unit roots. There is a long-run equilibrium relationship between taxation and manufacturing sector growth in Nigeria; and, the result confirmed that about $76 \%$ short-run adjustment speed from long-run disequilibrium. The coefficient of determination indicated that about 65\% of the variations in Manufacturing sector growth can be explained by changes in taxation variables. The study concludes that taxation has a causal relationship with the growth and development of manufacturing sector in Nigeria. The study recommends that Government and policy makers should check the tax laws in order to encourage the small and medium scale manufacturing industries to thrive in the economy. Tax administrators should be train and retrain to identify the importance of communication and dialogue in discharging their statutory responsibilities to the operators in the manufacturing sector. The policy makers should ensure proper integration of the financial sector; so that financial units can be strategically positioned and capable to intermediate funds in the manufacturing sector of the economy. Government and policy makers should implement policies that will increase the flow of investable funds and improves the capacity of investors in the manufacturing sector of the economy to grow.
\end{abstract}

Keywords: Causality Investigation, Taxation, Manufacturing Sector Growth, Nigeria.

\section{INTRODUCTION}

The growth and development of manufacturing sector in any market free economy also greatly depends on the efficient and effective management of tax policy (Afulagbi, 2018). However, taxation and manufacturing sector growth nexus had been identified as one of the areas in the financial economics literature that can quicken the growth and development of an economy such as Nigeria.The study carried out by (Oluitan, 2017) posited that manufacturing sector seems to have failed to meet the expectations of the Nigerian society in terms of its contributions to the Gross Domestic Product (GDP); because, the sector is unable to provide the required needs for the economy. Hence, Nigeria, like many other developing countries, is not a strong economy in the area of manufacturing. Thus, the sector has remained a major consumer of foreign exchange, rather than being a leading growth sector in socio-economic transformation in Nigeria. As a result, this might lead to poor industrial technologies that will bring about low competitive markets and reduced general welfare of the citizenry. The work of Olufayo and Fagite (2018) stated that apart from the revenue function it performs for the government, tax is also used to achieve the macroeconomic objectives from the manufacturing sector. Thus, the tax system is one of the most powerful levies available to any government to stimulate and guide its economic and social development. A study conducted by Akhorand and Ekundayo (2018) reaffirmed that irrespective of the knowledge of taxation as a veritable tool for raising revenue to meet government needs, its role in promoting growth and development in manufacturing sector growth of the economy cannot be overemphasized.

The work of Akaaand Criscent (2017) stressed that the challenges of the manufacturing sector come amidst of high corporate tax rates in Nigeria. Hence, the study conducted by Okorontha and 
Odoemena (2018) posits that taxation plays a role in the economy; because, tax policies, apart from generating revenue for the state, it also serves several other vital purposes such as; an avenue to protect infant industries, create incentive for investors to invest in manufacturing sector of the economy or to create incentive for other economic activities that capable of promoting growth and development. The pronouncements made by governments based on tax reforms, over the years havecreated tax incentives for businesses to thrive in the economy(Afuberoh\&Okoye, 2018). The taxes and resultant policies seem to have serious effect on the solvency, profitability, and other indicators of manufacturing sector growth in Nigeria. while studies on manufacturing sector focuses on its productivity and its performance on the economy. The study by AfuberohandOkoye (2018) revealed that there seems to be little or no attention on the relationship between the corporate/company's tax and its performance of the manufacturing sector. However, the question that prompted this study is whether there is a relationship between taxation and manufacturing sector growth in Nigeria. Consequently, the objective of this study is to ascertain the direction of the relationship between taxation and the manufacturing sector performance in Nigeria.

\subsection{Theoretical Framework}

The theoretical framework of the study is predicated on the expediency theory; which asserts that every tax proposal must pass the test of practicability. This appears to be the only consideration that will enable the authorities in choosing a tax proposal in the economy. This reasoning corroborates the work of Ajuegbe (2017) which justifies imposition of taxes for financing state activities by inferences, provides a basis, for apportioning the tax burden and between members of society. The study by Chiwendu (2019) stated that this proposition has a truth in it, since it is useless to have a tax which cannot be levied and collected efficiently. Thus, every group operators tries to protect and promote its own interests and authorities are often forced to reposition tax structure to accommodate these demands. In addition, the administrative set up may not be efficient to collect the tax at a reasonable cost of collection. Taxation provides a powerful set of policy tools to the authorities and should be effectively used for remedying economic and social ills of the society such as income inequalities, regional disparities, unemployment, cyclical fluctuations (Afuberoh\&Okoye, 2018). This study therefore focuses on the expediency theory which enables us to assess the extent to which the Nigerian tax system conforms to this scenario where the link between tax liability and manufacturing sector activities in the economy (Kolagbetu\&Funtua, 2017).

\subsection{Empirical Review}

Akaaand Criscent (2017) studied effect of taxation on economic growth of Nigeria (1994 -2014). The data collected were analyzed using relevant econometric models such as Augmented Dickey Fuller Test, Johansen Co integration test and error correction model. The result showed all the variables were stationary at first difference and co-integrated. In other words, the variables are all integrated of order one 1(1). The result also showed that there is a long run positive relationship between company income tax and petroleum profit tax while value added tax and Personal income was negatively related to economic growth.

Okwara, Cornelius and Amori (2018) examined the impact of tax revenue on the economic growth in Nigeria for the period of 1994-2016. The variables considered are: Gross Domestic Product (GDP) as a proxy for economic growth, Value Added Tax (VAT), and non-oil income (tax). To avoid spurious results, Ordinary Least Square (OLS) with the aids of Statistical Package for Social Sciences (SPSS) was used to test the significant impact of value added tax and non-oil income on Gross Domestic Product (GDP). The results revealed that non-oil income has significant impact on gross domestic product while value added tax has negative relationship and statistically insignificant for the period under review. The study concludes that tax revenue have significant impact on Nigerian economy growth.

Amos, Uniamikogbo and Aigienohuwa (2017) investigated tax revenue and economic growth of Nigeria, Data for the study were collected from secondary sources, the Statistical Bulletins of Federal Inland Revenue Service and the Central Bank of Nigeria respectively for the period 1995 to 2015. Econometric Model of Multiple Linear Regressions and Ordinary Least Square (OLS) technique were adopted to explore the relationship between GDP (the dependent variable) and a set of government income tax revenue heads over the period 1995 to 2015. Our findings showed that tax revenues that determine government economic growth are Petroleum Profit Tax and Company Income Tax. 
Akhorand and Ekundayo (2018) investigated the impact of tax revenue on economic growth from 1993 to 2017, research design used is time series and the data were analyzed using descriptive statistics, correlation, unit root test, co-integration test and error correction model regression. The result revealed that value added tax had a negative and significant impact on real gross domestic product. In the same vein, custom and excise duty had a negative and weakly significant impact on real Gross Domestic Product.

\section{MeTHODOLOGY}

The study adopted ex-post-facto research design to source requisite information. The study used Manufacturing sector output(MSO) was employed as the dependent variable to measure manufacturing sector growth; while, inflation rate (INFR), petroleum profit tax (PPT), value added tax (VAT) also employed as the independent variables as indicated on appendix 1.

\subsection{Model Specification}

Multivariate linear regression models are used to test the null hypotheses proposed for this study. Based on this, a model is adapted from the work of (Soyode\&Kajola, 2017). The model is stated as: $\mathrm{MSO}=f(\mathrm{VAT}, \mathrm{PPT})$

Where: $\mathrm{MSO}=$ Manufacturing sector output as proxy for manufacturing sector growth

VAT $=$ Valued Added Tax

PPT $=$ Petroleum Profit Tax

The above model is modified in this study by introducing inflation rate and as employed as independent variable. Hence, the modified model is stated as:

$\mathrm{MSO}=f(\mathrm{VAT}, \mathrm{PPT}, \mathrm{INFR})$

The econometric model can be written as:

$\operatorname{Ln}(\mathrm{MSO})=\mathrm{a}_{0}+\mathrm{a}_{1} \operatorname{LnVAT}+\mathrm{a}_{2} \mathrm{LnPPT}+\mathrm{Lna}_{3} \mathrm{INFR}+\mu$.

Where:

MSO = Manufacturing sector output as proxy for manufacturing sector growth.

VAT $=$ Valued Added Tax

PPT $=$ Petroleum Tax

INFR = Inflation Rate

$\mathrm{a}_{0}=$ Constant parameter, $\mathrm{a}_{1}-\mathrm{a}_{3}=$ Elasticity Co-efficient of each variable. $\mu=$ Stochastic error term, $\mathrm{Ln}$ $=$ The natural $\log$ of the variables. Log transformation is necessary to reduce the problem of heteroskedasticity because it compresses the scale in which the variables are measured, thereby reducing a tenfold difference between two values to a twofold difference (Gujarati, 2004).

\subsection{Data Presentation and Discussion}

The study used Manufacturing sector output (MSO) was employed as the dependent variable to measure manufacturing sector growth; while, inflation rate (INFR), petroleum profit tax (PPT), value added tax (VAT) also employed as the independent variables as indicated on appendix 1.

\subsection{Descriptive Statistics}

Table1: Descriptive statistics

\begin{tabular}{|l|l|l|l|l|}
\hline & \multicolumn{1}{|c|}{ MSO } & \multicolumn{1}{c|}{ VAT } & \multicolumn{1}{c|}{ PPT } & INFR \\
\hline Mean & 74568.45 & 70326.94 & 65375.70 & 38.05763 \\
\hline Median & 64536.03 & 63864.58 & 35261.79 & 32.14650 \\
\hline Maximum & 53867.63 & 63645.84 & 52310.79 & 28.10000 \\
\hline Minimum & 50123.46 & 53645.83 & 42523.67 & 24.10000 \\
\hline Std. Dev. & 66524.02 & 14869.05 & 47689.86 & 9.617132 \\
\hline Skewness & 0.285252 & 3.465248 & 1.0670 .69 & 0.185586 \\
\hline Kurtosis & 3.075432 & 14.19450 & 5.2562 .20 & 2.604247 \\
\hline Jarque-Bera & 0.460738 & 203.1536 & 12.83670 & 0.253744 \\
\hline
\end{tabular}




\begin{tabular}{|l|l|l|l|l|}
\hline \multicolumn{5}{|l|}{} \\
\hline Probability & 0.878895 & 0.000000 & 0.001612 & 0.821799 \\
\hline Sum & 262.3100 & 3173.310 & 596.4000 & 1486.929 \\
\hline Observations & 3268.357 & 653274.4 & 647.1700 & 2167.166 \\
\hline
\end{tabular}

Source: Author's computation with the use of E-view 9.1

Descriptive statistics on table 1 shows that Manufacturing sector output for the period under study had a mean value of $\$ 74,568.45$, value added tax had $\$ 70,326.94$ and petroleum profit tax had \$65,375.70 while inflation rate had 38\%. The Jarque-Bera statistic shows that two of the variables, namely manufacturing sector output and value added tax were normally distributed while valued added tax and inflation rate were highly skewed. Thus, the manufacturing sector output has a median of $\$ 64,536.03$ this implies that for the period under review the manufacturing sector output was very high. This is because there is a positive significant relationship between taxation and the manufacturing sector growth in Nigeria.

\subsection{Unit Root Test}

The test for stationary of the variables was done using the Augmented Dicker Fuller (ADF) Unit Root Test. The result on table 2 shows that all the variables are integrated at levels i.e. 1(1) at the 5\% or 1\% level of significance.

Table2: Unit Root Test Analysis

\begin{tabular}{|l|l|l|l|l|}
\hline Variables & $\begin{array}{l}\text { ADF test } \\
\text { Statistics }\end{array}$ & $\begin{array}{l}\text { Mackinnon critical } \\
\text { @ 5\% }\end{array}$ & $\begin{array}{l}\text { No of the time } \\
\text { difference }\end{array}$ & Remark \\
\hline MSO & 4.4370285 & -3.325349 & $1(1)$ & Stationary \\
\hline VAT & -3.8132454 & -1.602034 & $1(1)$ & Stationary \\
\hline PPT & -5.0163584 & -3.214209 & $1(1)$ & Stationary \\
\hline INFR & 3.2014232 & -2.013204 & $1(1)$ & Stationary \\
\hline
\end{tabular}

Notes: (1)1\% level of significance, $5 \%$ level of significance, $10 \%$ level of significance. The tests accepted at $5 \%$ level of significance. Decision rule -The critical value should be larger than the test statistical value for unit root to exist.

Source: Researcher's Estimation using- E-views 9.1

\subsection{Test for Co-Integration}

Hence, having found that all the variables are stationary at first difference, the next step is to perform Johansen co-integration procedure to ascertain whether Manufacturing sector output (MSO) has causality with value added tax (VAT), Petroleum profit tax (PPT) and inflation rate (INFR) are cointegrated in the same order. The results of the test are presented on table $\mathbf{3}$.

Table3: Multivariate Johansen's Co-Integration Test Result.

\begin{tabular}{|l|l|l|l|l|l|l|}
\hline $\begin{array}{l}\text { Null } \\
\text { hypothesis }\end{array}$ & $\begin{array}{l}\text { Alternative } \\
\text { hypothesis }\end{array}$ & Eigen value & $\begin{array}{l}\text { Likelihood } \\
\text { ratio }\end{array}$ & $\begin{array}{l}\text { Critical vales } \\
5 \%\end{array}$ & $\begin{array}{l}\text { Critical value } \\
1 \%\end{array}$ & $\begin{array}{l}\text { Hypothesized } \\
\text { No. of CE(s) }\end{array}$ \\
\hline $\mathrm{r}=0$ & $\mathrm{r}=1$ & 0.73547 & 66.35478 & 56.84 & 44.75 & None $* *$ \\
\hline $\mathrm{rd} \leq 1$ & $\mathrm{r}=2$ & 0.65374 & 56.03422 & 43.94 & 42.62 & At most 1 \\
\hline $\mathrm{rd} \leq 2$ & $\mathrm{r}=3$ & 0.55369 & 48.75839 & 37.46 & 36.05 & At most 2 \\
\hline $\mathrm{rd} \leq 3$ & $\mathrm{r}=4$ & 0.48244 & 24.37858 & 28.32 & 28.23 & At most 3 \\
\hline
\end{tabular}

Note* $(* *)$ denotes rejection of hypothesis at $5 \%(1 \%)$ significance level.

Source: E-views Econometrics 9.1.

Table4: Vector Error Correction Estimates Results

\begin{tabular}{|c|c|c|c|c|}
\hline \multicolumn{5}{|c|}{ Dependent Variable: MSO } \\
\hline \multicolumn{5}{|c|}{ Method: Least Squares, Time: 5:45 } \\
\hline \multicolumn{5}{|c|}{ Sample: $1990-2018$} \\
\hline \multicolumn{5}{|c|}{ Included observations: 29} \\
\hline Date: 08/06/2019 & Coefficient & Std. Error & $\mathrm{t}$-Statistic & Prob. \\
\hline$\left(\mathrm{ECM}_{-1}\right)$ & -0.763216 & 2.103240 & 18.03085 & -0.000002 \\
\hline $\operatorname{LnMSO}(-1)$ & 5.432783 & 0.048588 & 2.465369 & 0.000004 \\
\hline $\operatorname{LnMSO}(-2)$ & 4.435240 & 1.002364 & 1.563738 & 0.000454 \\
\hline $\mathrm{C}$ & 3.835437 & 0.022537 & 6.354784 & 0.000464 \\
\hline
\end{tabular}




\begin{tabular}{|l|l|l|l|l|}
\hline \multicolumn{5}{|l|}{} \\
\hline Ln(VAT)(-1) & 5.321736 & 0.586309 & 4.756465 & 0.000034 \\
\hline LN(PPT)(-2) & 5.253783 & 0.007653 & 3.004758 & 0.000009 \\
\hline R-squared & 2.753667 & 0.059724 & 3.957665 & 0.000024 \\
\hline Adjusted R-squared & 0.651020 & Mean dependent var & 21.20543 \\
\hline S.E. of regression & 0.591032 & S.D. dependent var & 12.02435 \\
\hline Sum squared resid & 16.04756 & Akaike info criterion & 103.1023 \\
\hline Log likelihood & 324.1520 & Schwarz criterion & 15.03252 \\
\hline Durbin-Watson stat & -164.1673 & F-statistic & 9.957680 \\
\hline
\end{tabular}

Source: Author's computation with the use of E-view 9.1

There is a long-run equilibrium relationship between taxation and manufacturing sector growth in Nigeria; and, the result confirms that about $76 \%$ short-run adjustment speed from long-run disequilibrium. From table 4 the coefficient of determination $\left(\mathrm{R}^{2}=0.651020\right)$ indicates that about $65 \%$ of the variations in Manufacturing sector output can be explained by changes in taxation variables (VAT, PPT,INFR) in Nigeria. This implies that a significant portion of economy is explained by taxation variables. The p-value of (0.00000) indicates that there is a significant relationship between taxationandManufacturing sector growth in Nigeria; this is because, the F-probability is statistiscally zero. This means that taxation has a significant relationship withManufacturing sector growth in Nigeria; because, the influence of the explanatory variables on the dependent variable is statistically significant and this is also confirmed by the F-probability which is statistically zero.

\subsection{Causality Test}

The results of the Granger causality test on table 5 indicate that the Manufacturing sector output (MSO) has causality with value added tax (VAT), Petroleum profit tax (PPT) and inflation rate (INFR).This implies that there is a causal relationship between taxation and the performance of manufacturing sector in Nigeria.

Table5: Result of Pair wise Granger-Causality Test (1990-2018) with 2-period Lag length

\begin{tabular}{|l|l|l|l|l|}
\hline \multicolumn{1}{|c|}{ Null Hypothesis: } & Obs & \multicolumn{1}{|c|}{ F-Statistic } & Probability & \multicolumn{1}{c|}{ Decision } \\
\hline VAT does not Granger Cause MSO & 27 & 6.04856 & 0.00124 & Causality \\
\hline MSO does not Granger Cause VAT & 5.15363 & 0.00013 & Causality \\
\hline PPT does not Granger Cause MSO & 27 & 8.25364 & 0.00022 & Causality \\
\hline MSO does not Granger Cause PPT & 7.16374 & 0.00067 & Causality \\
\hline INFR does not Granger Cause MSO & 27 & 6.80656 & 0.00031 & Causality \\
\hline MSO does not Granger Cause INFR & 5.16357 & 0.00081 & Causality \\
\hline VAT does not Granger Cause MSO & 27 & 7.25342 & 0.00120 & Causality \\
\hline MSO does not Granger Cause VAT & 3.53647 & 0.00123 & Causality \\
\hline VAT does not Granger Cause PPT & 27 & 4.14355 & 0.00062 & Causality \\
\hline PPT does not Granger Cause VAT & 9.02436 & 0.00028 & Causality \\
\hline INFR does not Granger Cause VAT & 27 & 7.30253 & 0.00136 & Causality \\
\hline VAT does not Granger Cause INFR & 5.16345 & 0.00073 & Causality \\
\hline
\end{tabular}

Note: The decision rule of a causality test states that if the probability value of the estimate is higher than the $5 \%$ (or 0.05) level of significance, we accept the null hypothesis, and vice versa.

Source: E-views Econometrics 9.1

\section{CONCLUSION AND RECOMMENDATIONS}

The study concluded that taxation has a causal relationship with the manufacturing sector growth in Nigeria. This is evident from the results of the test shown on table 5.This implies that tax variables are statistically significant in explaining the growth and development of Nigerian economy. This corroborates the work ofAjiuefra and Ohuigbo (2018) which revealed a positive significant relationship between taxation and manufacturing sector of the Nigerian economy.The study recommends that Government and policy makers should check the tax laws in order to encourage the small and medium scale manufacturing industries to thrive in the economy. Tax administrators should be train and retrain to identify the importance of communication and dialogue in discharging their statutory responsibilities to the operators in the manufacturing sector.The policy makers should ensure proper integration of the financial sector; so that financial units can be strategically positioned and capable to intermediate funds in the manufacturing sector of the economy. Government and policy 
makers should implement policies that will increase the flow of investable funds and improves the capacity of investors in the manufacturing sector of the economy to grow.

\section{CONTRIBUTION TO KNOWLEDGE}

The study was able to modify the model, expand the existing literature, empirical review, geographical spread and updated data that will enable researchers and scholars to use it for further studies. The study concludes that taxation has a direct causal relationship withthe manufacturing sector growth in Nigeria.

\section{REFERENCES}

[1] Akhor, S.O \&Ekundayo, O.U(2018). The impact of indirect tax revenue on economic Growth: The Nigeria experience.Igbinedion University Journal of Accounting, 2(1), 62-63

[2] Afuberoh, D\&Okoye, F (2018).An empirical investigation of the effect of taxation on Macroeconomic Performance in Nigeria: Journal of Economics and Sustainable Development,6(6), 12-28.

[3] Aliyu, S.R.U. (2018). Impact of oil price shock and exchange rate volatility on economic growth in Nigeria: An empirical investigation. Research Journal of International Studies, 23(8), 12-23.

[4] Ayinde, T.O. (2014). The impact of exchange rate instability on manufacturing performance in Nigeria. Fountain Journal of Management and Social Sciences. 3(2) 83-92.

[5] Azeez, B.A., Kolapo, F.T \&Ajayi, L.B (2017). Effect of exchange rate volatility on macroeconomic performance in Nigeria. Interdisciplinary Journal of Contemporary Research in Business. 4(1), 149-155.

[6] Bala, S.A. \& Hassan, A. (2018). Exchange rate and stock market interactions: Evidence from Nigeria. Arabian Journal of Business and Management Review, 23(8), 123-134.

[7] Chijioke, N; Ofurum, Leonard; Bossco, E.\&Amaefule, T(2017). Impact of e-taxation on Nigeria's revenue and economic growth: A pre-post analysis. International Journal of Finance and Accounting, 7(2), 9-26.

[8] Chiwendu, D. (2019). Impact of taxation on manufacturing sector performance in Nigeria. International Journal of Managerial Studies, 12(6), 119-128.

[9] Garba, S.L (2015). Tax revenue and economic growth in Nigeria, Department of Accounting, Faculty of Administration Ahmadu Bello University, Zaria

[10] Mohammad, A.R;Sayema, H.B \&Bazlul, H.K (2017). Exchange rate and economic growth: An empirical assessment for Bangladesh. Journal of South Asian Development, 12(1), 42 -64.

[11] Nasir, S. \&Valdrina, S. (2017). The effects of exchange rate on economic growth in the Republic of Macedonia. ECOFORUM, 6(3), 13-23.

[12] Nwoye, U.J., Obiorah, J.N. \&Ekesiobi, C. (2015). Effect of Nigeria macroeconomic environment on the performance of the national economy: Implications. Journal of Academic Research in Business and Social Sciences, 5(6), 42-51.

[13] Ogun, O (2016). Real exchange rate behaviour and non-oil export growth in Nigeria. African Journal of Economic Policy, 11(1), 23-34.

[14] Okorontha, C. F. \&Odoemena, I. U. (2018). Effects of exchange rate fluctuations on economic growth of Nigeria. International Journal of innovative Finance and Economics Research 4(2), 1-7.

[15] Olufayo, M.B. \&Fagite, B.A (2018). Exchange rate volatility and sectoral export of Nigeria: Case of oil and non-oil Sectors. Journal of Economics and Sustainable Development, 5(4), 10-23.

[16] Rogoffs, K. \& Reinhart, F (2018). Exchange rate volatility and productivity Growth: The role of financial development. Journal of Monetary Economics, 56(4), 494-513.

Appendix1: Taxation and Manufacturing Sector Growth in Nigeria (1990-2018)

\begin{tabular}{|l|l|l|l|l|}
\hline YEAR & $\begin{array}{c}\text { Manufacturing } \\
\text { Sector Output } \\
\text { (N Billion) }\end{array}$ & $\begin{array}{c}\text { Valued Added Tax } \\
\text { (N'Billion) }\end{array}$ & $\begin{array}{c}\text { Petroleum Profit } \\
\text { Tax(N' Billion) }\end{array}$ & Inflation Rate (\%) \\
\hline 1990 & 40.8 & 21.4 & 31.2 & 20.9 \\
\hline 1991 & 98.6 & 30.9 & 58.0 & 7.7 \\
\hline 1992 & 144.4 & 45.7 & 109.9 & 23.2 \\
\hline 1993 & 165.9 & 89.5 & 121.5 & 39.6 \\
\hline 1994 & 219.9 & 143.2 & 205.6 & 5.5 \\
\hline 1995 & 295.8 & 165.6 & 218.8 & 5.4 \\
\hline 1996 & 350.6 & 162.8 & 206.1 & 10.2 \\
\hline 1997 & 382.6 & 755.1 & 950.7 & 38.3 \\
\hline 1998 & 395.8 & 562.6 & $1,309.5$ & 40.9 \\
\hline
\end{tabular}


A Causality Investigation of Taxation and Manufacturing Sector Growth in Nigeria (1990-2018)

\begin{tabular}{|l|l|l|l|l|}
\hline \multicolumn{5}{l}{} \\
\hline 1999 & 426.2 & 845.7 & $1,241.7$ & 7.5 \\
\hline 2000 & 468.0 & 837.4 & 751.9 & 13 \\
\hline 2001 & 535.8 & 862.5 & $1,189.0$ & 44.5 \\
\hline 2002 & 507.8 & 985.0 & $1,945.7$ & 57.2 \\
\hline 2003 & 465.8 & $1,358.2$ & $1,868.0$ & 57 \\
\hline 2004 & 349.3 & $1,512.7$ & $1,744.2$ & 72.8 \\
\hline 2005 & 408.4 & $2,080.2$ & $3,087.9$ & 29.3 \\
\hline 2006 & 478.5 & $1,987.0$ & $4,602.8$ & 8.5 \\
\hline 2007 & 520.9 & $2,800.9$ & $7,246.5$ & 10 \\
\hline 2008 & 585.6 & $3,108.5$ & $7,324.7$ & 6.6 \\
\hline 2009 & 612.3 & $3,912.0$ & $8,309.8$ & 6.9 \\
\hline 2010 & 643.1 & $5,593.2$ & $10,387.7$ & 18.9 \\
\hline 2011 & 694.8 & $5,480.7$ & $48,606.3$ & 12.9 \\
\hline 2012 & 761.5 & $8,164.0$ & $12,011.5$ & 14 \\
\hline 2013 & 823.9 & $10,995.9$ & $23,236.7$ & 10.1 \\
\hline 2014 & $8,685.4$ & $9,766.6$ & $18,139.3$ & 11.5 \\
\hline 2015 & $8,942.8$ & $9,439.4$ & $15,262.0$ & 8.6 \\
\hline 2016 & $9,432.2$ & $10,538.8$ & $19,960.5$ & 6.6 \\
\hline 2017 & $9,65.49$ & $11,076.1$ & $28,845.2$ & 32.4 \\
\hline 2018 & $10,37.48$ & $11,836.4$ & $29,746.5$ & 18.3 \\
\hline
\end{tabular}

Sources: Central Bank of Nigeria Statistical Bulletin, 2018.

Citation: Andabai, Priye Werigbelegha Ph.D. "A Causality Investigation of Taxation and Manufacturing Sector Growth in Nigeria (1990-2018)" International Journal of Managerial Studies and Research (IJMSR), vol 7, no. 10, 2019, pp. 1-7. doi: http://dx.doi.org/10.20431/2349-0349.0710001.

Copyright: () 2019 Authors. This is an open-access article distributed under the terms of the Creative Commons Attribution License, which permits unrestricted use, distribution, and reproduction in any medium, provided the original author and source are credited. 